\title{
LATIN IN SOUTH AFRICA: TWO INSCRIPTIONS ON THE HARTBEESPOORT COMMEMORATIVE ARCH
}

\author{
J Hilton (University of Natal, Durban)
}

\begin{abstract}
'There are languages that sing, there are others that draw or paint. Latin engraves, and what it engraves is ineradicable. One might say that something that is not universal or eternal cannot be Latin.' Ferdinand Brunétière, quoted by MarieMadeleine Martin, Le latin immortel (Diffusion de la Pensée Française: Chiré-enMontreuil 1971: 247). ${ }^{1}$
\end{abstract}

The tradition of engraving inscriptions in Latin continues in many countries today, including South Africa. War memorials, school mottoes, epitaphs, degree certificates, and commemorative Latin texts in general are still found in public places in this country. An example dated as late as 1994 exists in the Western Cape. ${ }^{2}$ During this long timespan the practice has not gone uncontested, of course; the court of Louis XIV in France upheld the merits of French rather than Latin as the language of official inscriptions during the wider 'Quarrel between Ancients and Moderns' in the seventeenth century (Waquet 2001:238), and today the vernacular languages are widely preferred. Nevertheless, many private individuals and public corporations want their inscriptions done in Latin. Where knowledge of the language is lacking, Latinists in South African universities are often asked to provide it. As an alternative to free composition in Latin, commemorators sometimes favour quotations from the ancient authors and sacred scripture.

Two interesting examples of such literary inscriptions occur on the Roman arch on the Hartbeespoort Dam, which is located 34 kilometres west of Pretoria (see Fig. 1 below). ${ }^{3}$ The name Hartbeespoort Dam is the correct form, as the name derives

The quotation is taken from Waquet 2001:262.

The following words, for example, are found inscribed on a fountain at Franschhoek: FONS IN MEMORIAM FAMILIAE MEAE FRANSCHHOEK AMANTIS DATVS / EST ET DONO ET GAVDIO VIVIS NASCITVRISQVE DEO VOLENTE / ARTHVR MCWILLIAM SMITH MXMIV. 'This fountain was donated in memory of my family who love Franschhoek and as a gift and source of joy to those who live there and those who by the grace of god will be born there. Arthur McWilliam Smith 1994.' I owe this reference to Mr Mark Hermans of the University of the Western Cape.

3 I would like to thank Miss Riona Naidu for bringing these inscriptions to my attention and for making photographs of the arch available to me. I would also like to thank Dr Christoff Zietsman for obtaining information from Albrecht Holm of the Hartbeespoort Heritage Association concerning the history of the dam. Research was carried out on my behalf by Emmerentia Van Rensburg in libraries in Brits, Schoemansville and Kosmos, as well as the State Archives and newspaper archives in Pretoria. I am grateful to Ms Van Rensburg for her efforts in uncovering information on the arch and dam. The anonymous readers of this article also suggested useful changes. 
from the eponymous antelope found in the region (rather than from the fact that cattle in the area needed to be tough in order to survive the harsh conditions there). ${ }^{4}$

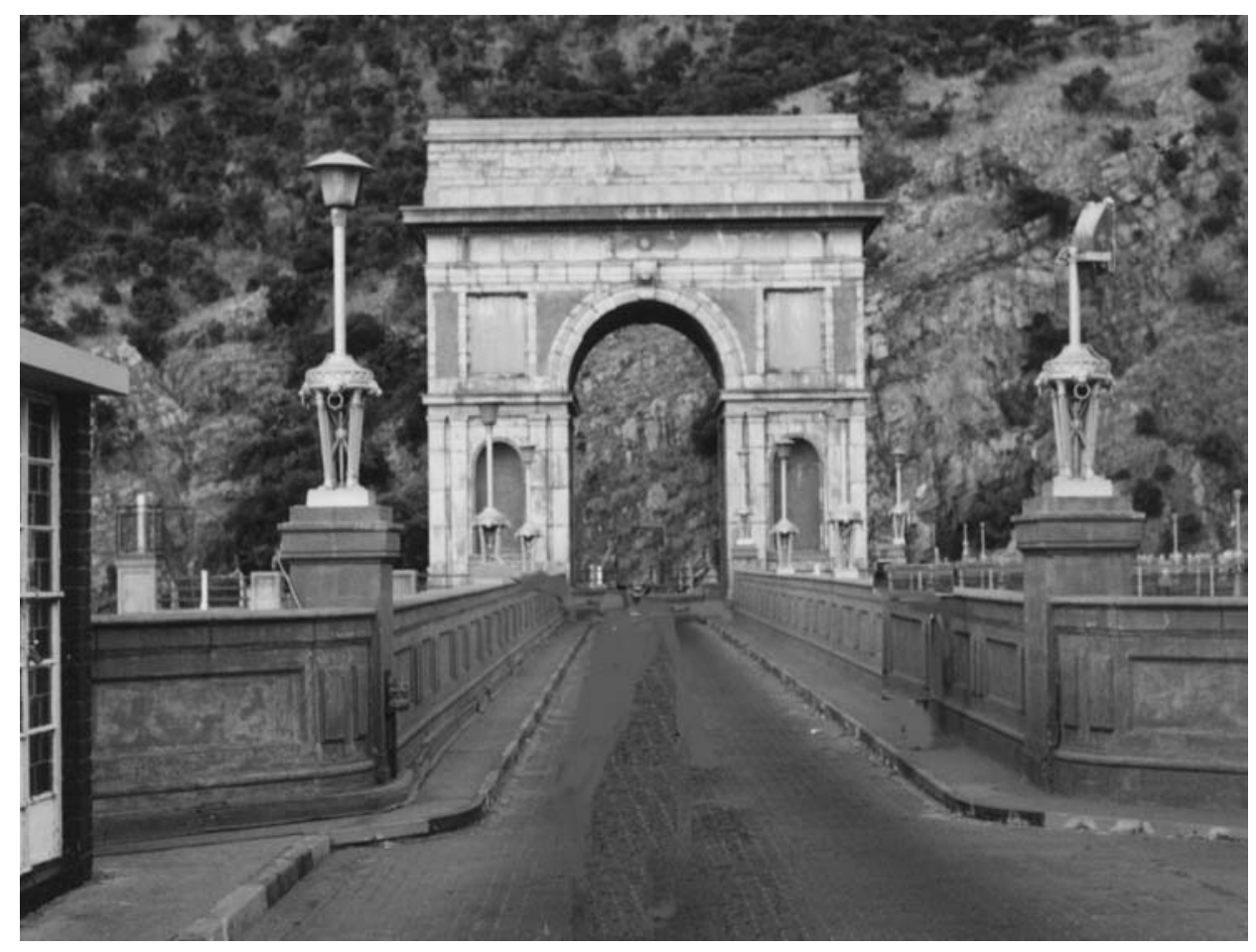

Fig. 1: The Arch on the Hartbeespoort Dam today (Photo by R. Naidu).

The Hartbeespoort Dam project originated as a private venture by Hendrik Schoeman who constructed a dam known as the Sophia Dam in the poort in 1898 to control the flow of the Crocodile River. This first dam was washed away in 1909. Government involvment was obtained for a more ambitious construction and parliament approved this scheme in the form of the Hartebeestpoort Act No. 32 of 1914. The intervention of the First World War caused inevitable delays and the dam was only completed by 'poor white' workers working for the John Barrow engineering firm under the direction of the engineer F.W. Scott in 1923. ${ }^{5}$ The labours of those workers who lost their lives during the dangerous construction of the dam is commemorated by a monument (De Beer 1975:387 f). The dam is used for the generation of electrical power by means of a turbine, provision of drinking water for Pretoria and Johannesburg, agricultural irrigation and recreation.

\footnotetext{
4 Cf. Kokot 1970:444, De Beer 1975:381. Mulder 1975b:1 suggests that the name derives from the tough cattle in the area.

5 Statistics on the dam are given in de Beer 1975:400 f.; Olivier 1976:196.
} 
The arch was probably built in imitation of the famous Arc de Triomphe in Paris and is fourteen metres high. ${ }^{6}$ It is located on the western buttress of the dam and was constructed out of pre-cast concrete blocks covered with light blue and yellow tiles. The architect Mr. Williamson designed the structure and it was erected by the firm of John Barrow. Economically, the dam may have been intended to address the "poor white' problem in the years of the Great Depression after the First World War by providing work for the unemployed. The idea of erecting a monument on the wall appears therefore to have been intended to commemorate the upliftment of those involved in the building rather than merely to mark its completion or to celebrate the Union and the reconciliation of Boer and Brit. ${ }^{7}$ In addition to providing employment during the construction of the dam, the project made successful farming in the region possible. Even today a number of towns such as Kosmos, Brits and Schoemansville derive employment from the recreational facilities around the dam.
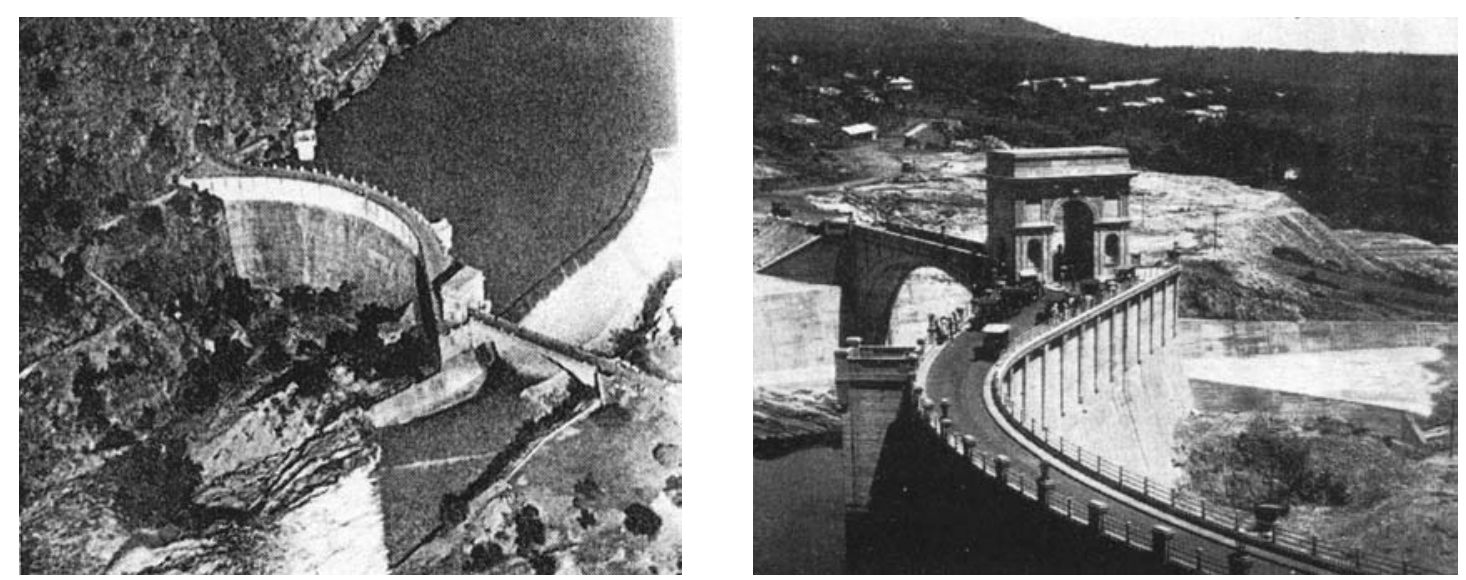

Fig. 2, 3: Views of the Hartbeespoort Dam wall and arch on completion in 1923. ${ }^{8}$

The Roman practice of erecting triumphal arches developed out of the use of such structures in functional buildings such as bridges and aqueducts, and made possible the erection of tall edifices such as the Colosseum. ${ }^{9}$ A more specific model was the elaborate town entrance gateway, known in Italy and Asia Minor from the third or fourth centuries BC. ${ }^{10}$ The positioning of an arch across a road transforms it into an

6 Many other famous examples of the Roman triumphal arch exist, from the Marble Arch in London to the 'Gateway to India' in Calcutta.

7 These suggestions are mentioned by Mr. Albrecht Holm of the Hartbeespoort Heritage Association, personal communication forwarded to me by Dr Christoff Zietsman, dated 13 March, 2002.

8 These photographs are taken from an anonymous article published by Department of Water Affairs and Forestry (no date or pagination).

9 The use of arches to strengthen tall structures is discussed by Vitruvius De Arch. 6.8.3-4.

10 Robertson $1964^{2}: 293$ describes triumphal arches as 'an unattractive Roman invention' (ibid.). A full catalogue of Roman triumphal arches is given by Anderson \& Spiers 1927:114-123. 
ambiguous transitional node; it threatens to obstruct the way while allowing passage beneath it. ${ }^{11}$

The connection between triumphal processions and arches is made in the first recorded case, the erection of three fornices ${ }^{12}$ by L. Stertinius in 196 BC in celebration of his victories in Spain (though he did not bother to obtain the honour of a formal triumph from the senate).

L. Stertinius ex ulteriore Hispania, ne temptata quidem triumphi spe, quinquaginta milia pondo argenti in aerarium intulit, et de manubiis duos fornices in foro bouario ante Fortunae aedem et matris Matutae, unum in maximo circo fecit et his fornicibus signa aurata imposuit (Livy 33.27).

L. Stertinius, who did not even try to obtain the triumph he hoped for, deposited 50,000 pounds of silver into the public treasury from Further Spain, and with the proceeds he erected two arches in the Forum Boarium in front of the temples of Fortuna and Mater Matuta, and one in the Circus Maximus. On these three structures he placed gilded statues.

The famous arch of Titus (erected in AD 81) with its depiction of the seven-branched candelabrum from Jerusalem confirms the use of arches in triumphal celebrations. As in the Hartbeespoort case, the Roman arches were often designed to allow traffic to pass through them, reminding travellers repeatedly of the message they were constructed to advertise. ${ }^{13}$ Like the Roman custom of making defeated enemies pass beneath a yoke, the triumphal arch enforces passers-by into submission. This is especially clear in the case of the arch of Titus, since elaborate depictions of the triumphal procession occur inside the arch itself and can only be viewed effectively from within it. In the Roman context such monuments formed part of the personality cult of the emperors, a practice extended particularly by Augustus, and every inch of the surfaces of the facades was used to depict the achievements of the current imperial regime. For this reason they were erected in busy public places and bore prominent inscriptions. Of greater relevance for the Hartbeespoort arch is the fact that such structures were sometimes erected to mark the completion of public works, such as a new road or bridge. The resemblance between the Roman arch on the bridge at Alcantara in Spain (see Fig. 4), for example, is strikingly similar to the Hartbeespoort one (see Fig. 3).

11 For a perceptive discussion of the spatial significance of Roman arches, see MacDonald 1986:2.75-99.

12 The Roman word for 'arch' (fornix) gives us the English word 'fornicate' from the practice of prostitutes entertaining their clients within the arches of the aqueducts.

13 Mortimer Wheeler (1964:156) points out that this was not always the case. The Severan arch in Rome, for example, was designed in such a way as to prevent traffic from passing through it. 


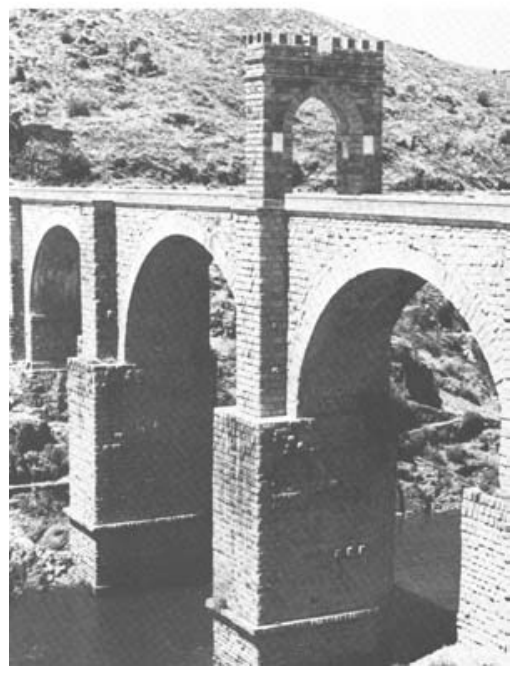

Fig. 4: Arch on bridge at Alcantara, Spain (early 2 nd century)

The two inscriptions on the eastern and western sides of the Hartbeespoort arch were mottoes of the Department of Irrigation at the time. ${ }^{14}$ The first inscription is from the Vulgate translation of Isaiah 43.19-21:

glorificabit me bestia agri dracones et strutiones

quia dedi in deserto aquas flumina in invio ${ }^{15}$

ut darem potum populo meo electo meo.

'The beasts of the field, the serpents and ostriches will glorify me Because I provided waters and rivers in the pathless desert So that I might give drink to my chosen people.'

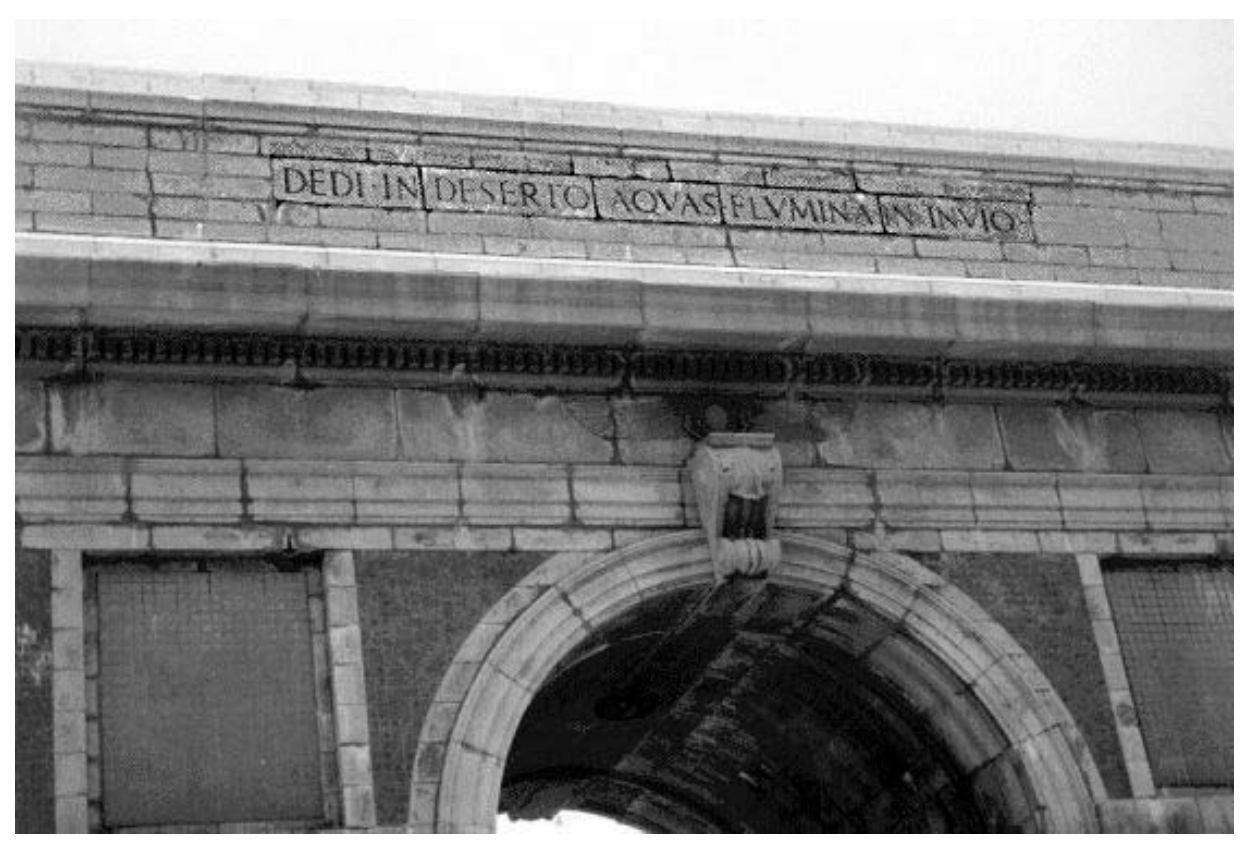

Fig. 5: The Isaiah inscription

14 The inscriptions are briefly discussed by Mulder 1975a:5. Mulder did not identify the Varro inscription.

15 In Afrikaans: "Ek sal water giet op die dorsland en strome op die dröe grond." 


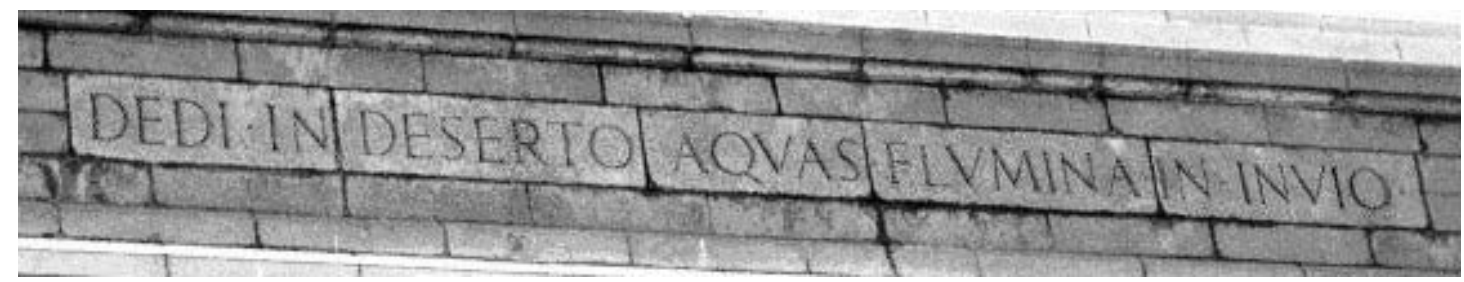

Fig. 6: Detail of the Isaiah inscription

The second inscription consists of an abbreviated version (sine aqua arida ac misera agri cultura 'without water agriculture is dry and harsh') of the first sentence of M. Terentius Varro's Res Rusticae. ${ }^{16}$ The full version is:

nec non etiam precor Lympham ac Bonum Euentum, quoniam sine aqua omnis arida ac misera agri cultura, sine successu ac bono euentu frustratio est, non cultura (Varro Res Rusticae 1.1).

'I pray especially to the spirits of water and good luck, since without water all agriculture is barren and harsh, and without progress and good luck it is frustration not cultivation.'

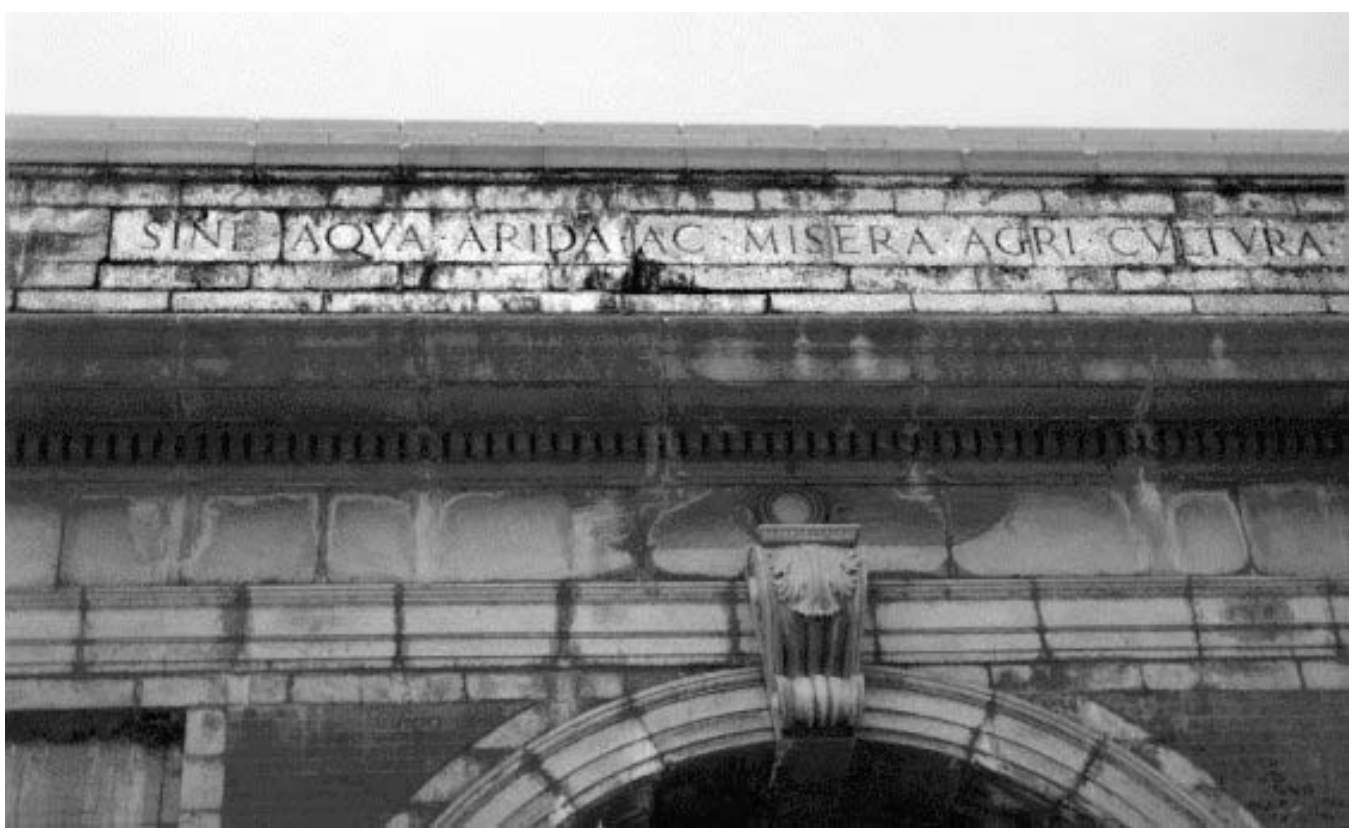

Fig. 7: The Varro inscription

16 In Afrikaans: "Sonder water is die boerdery maar droog en ellendig." 


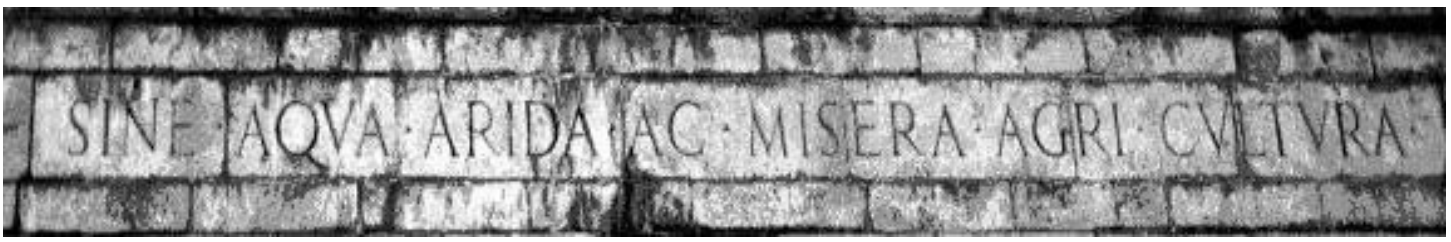

Fig. 8: Detail of the Varro inscription

The Varro inscription illustrates the importance attached to irrigation schemes by Roman farmers. ${ }^{17}$ Book 8 of Vitruvius' De Architectura shows that the Romans were well aware of the importance of water for life, well-being, and a number of other important things (including good teeth, intelligence, a fine singing voice, and beauty, cf. 8.22-24).

The fact that the rainy season does not coincide with the growing season for crops in Italy makes irrigation vital for successful agriculture (White 1970:146). The mountainous terrain of the Italian peninsula and underground reservoirs of water made irrigation feasible to some limited extent. Irrigation was used for pastures, vegetable gardens (a profitable enterprise according to Cato $A g r$. 1.7; cf. Columella Rust. 10.47-49), cropping (Virg. G. 1.107-109-perhaps exceptionally), orchards, and vineyards. Water for irrigation was led from springs, streams or wells, but apparently without the aid of mechanical devices such as water-wheels, suction pumps (cf. Vitruvius 10.7.1) or the shadouf (for all these methods, cf. Pliny $H N$ 19.60). ${ }^{18}$ Likewise, despite their economic importance, dams do not appear to have been constructed in Italy and the few examples we have are to be found in the much drier climates of Judaea and North Africa (see Vita-Finzi 1961, 1965). Cisterns for the supply of agricultural water are also found at Lepcis Magna (White 1970:417 and plate 13-15), but Columella (1.5.2) suggests that cisterns in Italy were normally constructed for drinking water. The techniques of irrigation employed in Egypt and Mesopotamia were also generally not employed in Italy (Hill 1984:18-20): these include 'Basin Irrigation', in which low-lying land adjacent to an elevant river was periodically flooded, 'Perennial Irrigation' by a grid of interconnected sluices, 'Terrace Irrigation' on steeply sloping land, and 'Wadi Irrigation' in which flash floods were dammed and distributed to agricultural land. In Egypt irrigation of fields was so commonplace that a contract for irrigation could be leased out (Nielsen 1995:179-88).

Thus, while irrigation was clearly essential for agriculture in Italy, it was clearly not comparable in sophistication with systems employed in the Middle East. Varro's invocation to Lympha and Bonus Eventus must have been largely based on

17 Cf. White (1970:146-72) on which the following is largely based.

18 For the debate on the use of technology for irrigation, see White 1970:157; Hill 1984:127-79. 
bitter experience. No doubt he would have been greatly impressed by the Hartbeespoort Dam.

\section{BIBLIOGRAPHY}

Anderson, W J \& Spiers, R P 1927. The Architecture of Ancient Rome: An Account of its Historic Development. New York: Books for Libraries Press.

Anonymous article, (no date). Hartbeespoort Dam: Hartbeespoort Government Water Scheme. Department of Water Affairs and Forestry.

De Beer, B K 1975. Agter die Magalies. Fontainebleau: Postma Publikasies.

Kokot, D E 1970. Hartbeespoort Government Waterworks, pp. 443-444 in Standard Encyclopaedia of Southern Africa. Cape Town: Nasou Beperk.

Hill, D 1984. A History of Engineering in Classical and Medieval Times. Beckenham: Croom Helm.

MacDonald, W L 1986. The Architecture of the Roman Empire. Volume II: An Urban Appraisal. New Haven and London: Yale University Press.

Mulder, G R 1975a. Hartbeespoort se damwal koepel. Schoemansville Nuusbrief / Newsletter.

Mulder, G R 1975b. Schoemansville: Hartbeespoort en sy vorige benaminge. Schoemansville Nuusbrief / Newsletter.

Nielsen, B E 1995. Application for a Lease of Vineyard Irrigation. ZPE 106:179-88.

Olivier, H 1976. Great Dams in Southern Africa. New York: Purnell.

Vita-Finzi, C \& Brogan, O 1965. Roman dams on the Wadi Megenin. Libya Antiqua 2:65.

Robertson, D S 1964². A Handbook of Greek \& Roman Architecture. Cambridge: Cambridge University Press.

Sear, F 1982. Roman Architecture. New York: Cornell University Press.

Waquet, F (tr. John Howe) 2001. Latin or the Empire of a Sign. London and New York: Verso

Wheeler, M 1964 .Roman Art and Architecture. London: Thames \& Hudson.

White, K D 1970. Roman Farming. London:Thames \& Hudson.

White, K D 1984. Greek and Roman Technology. London: Thames \& Hudson. 